\title{
Development of Predictive Growth Models for Staphylococcus aureus and Bacillus cereus on Various Food Matrices Consisting of Ready-to-Eat (RTE) Foods
}

\author{
Kyung Ah Kang, Yoo Won Kim, and Ki Sun Yoon* \\ Department of Food and Nutrition, Research Institute of Human Ecology, Kyung Hee University, \\ Seoul 130-701, Korea
}

\begin{abstract}
We developed predictive growth models for Staphylococcus aureus and Bacillus cereus on various food matrices consisting primarily of ready-to-eat (RTE) foods. A cocktail of three $S$. aureus strains, producing enterotoxins A, C, and D, or a $B$. cereus strain, were inoculated on sliced bread, cooked rice, boiled Chinese noodles, boiled bean sprouts, tofu, baked fish, smoked chicken, and baked hamburger patties at an initial concentration of $3 \log \mathrm{CFU} / \mathrm{g}$ and stored at $8,10,13,17,24$, and $30^{\circ} \mathrm{C}$. Growth kinetic parameters were determined by the Gompertz equation. The square-root and Davey models were used to determine specific growth rate and lag time values, respectively, as a function of temperature. Model performance was evaluated based on bias and accuracy factors. S. aureus and B. cereus growth were most delayed on sliced bread. Overall, $S$. aureus growth was significantly $(p<0.05)$ more rapid on animal protein foods than carbohydrate-based foods and vegetable protein foods. The fastest growth of $S$. aureus was observed on smoked chicken. B. cereus growth was not observed at 8 and $10^{\circ}$ C. B. cereus growth was significantly $(p<0.05)$ more rapid on vegetable protein foods than on carbohydrate-based foods. The secondary models developed in this study showed suitable performance for predicting the growth of $S$. aureus and $B$. cereus on various food matrices consisting of RTE foods.
\end{abstract}

Key words: $S$. aureus, B. cereus, animal protein foods, food matrices, predictive modeling

\section{Introduction}

Recently, the ready-to-eat (RTE) food industry has expanded due to changes in customer consumption patterns. In particular, convenience stores have been established as new distribution channels, and supply various RTE foods such as hamburgers, sandwiches, kimbab, and salads, which are consumed without heat processing (Park et al., 2005). In Korea, many outbreaks of foodborne disease have been attributed to the consumption of RTE foods. Foodborne illness outbreaks due to RTE foods greatly increased from 77 cases in 2002 to 354 cases in 2008. In 2009,809 of all food poisoning cases (1,831 cases) in Korea were caused by bacteria, where $23.4 \%$ of bacterial foodborne illnesses were caused by Staphylococcus aureus and $3.2 \%$ by Bacillus cereus (KFDA, 2009). Moreover,

\footnotetext{
*Corresponding author: Ki Sun Yoon, Department of Food and Nutrition, Research Institute of Human Ecology, Kyung Hee University, Seoul 130-701, Korea. Tel: 82-2-961-0264, Fax: 82-2-961-0261, E-mail: ksyoon@khu.ac.kr
}

such foodborne illnesses were mainly caused by RTE foods such as kimbab, a lunch box, and seasoned greens, which were prepared at retail stores (Kim et al., 2005). Recently, the Korea Food and Drug Administration has regulated the microbial standards of pathogens on RTE foods; S. aureus and B. cereus should not exceed 100 CFU/g and $1000 \mathrm{CFU} / \mathrm{g}$, respectively (KFDA, 2008).

$S$. aureus has been recognized as an indicator of the poor hygiene of foods and processing plants, and is a major cause of food gastroenteritis worldwide (Simon and Sanjeev, 2007). S. aureus is a Gram-positive bacterium, commonly occurring in grape-like clusters. If environmental conditions such as time and temperature during food storage and preparation allow the growth of S. aureus, staphylococcal enterotoxins may be produced, offering potential harm to consumers (Sneed et al., 2004). There are several studies reporting the presence of $S$. aureus in RTE and perishable foods including raw pork or smoked ham (Atanassova et al., 2001), poultry products (Pepe et al., 2006), milk (Fujikawa and Morozumi, 2006), fish (Hiraki et al., 1998), or foods that are pre- 
pared in advance before consumption and stored after preparation without adequate refrigeration (Roberts, 1986). Furthermore, the presence of $S$. aureus on the work surfaces and utensils of foodservice outlets has been widely demonstrated by several studies (Gibson et al., 1988; Hiraki and Suzuki, 1999). These characteristics enable $S$. aureus to grow and survive in a wide range of environmental conditions as well as to persist in stressful environments (e.g. dry surfaces) for long periods.

The presence of $B$. cereus has been reported in a variety of foods including milk and dairy products, meat and meat products, spices, dried products, cereals, especially rice, and eggs (Kramer and Gilbert, 1989). B. cereus is a Gram-positive, spore-forming, and facultative anaerobe that grows best under aerobic conditions (Granum, 1994). It is a common food contaminant and is an etiological agent of two distinct forms of illness, i.e., emetic and diarrheal. Carlin et al. (2006) observed different percentages in spore germination at chilled temperatures among $B$. cereus genetic groups.

A predictive model is a mathematical expression that describes the growth, survival, and inactivation of foodborne microorganisms. Such models have been used extensively to predict the safety of foods under various environmental conditions. Since the growth and survival of microorganisms are very much affected by the model media used in the research for model development, it is very important to consider a model food's characteristics such as its food matrix and $\mathrm{pH}$, which may influence the growth of microorganisms (Gibson et al., 1988). This study aimed to develop predictive growth models for $S$. aureus and B. cereus on various food matrices. The developed models will be used to quantify the effect of temperature on the growth of $S$. aureus and B. cereus on RTE foods according to the characteristics of various food matrices, as well as to determine the shelf-life of RTE foods at the retail market.

\section{Materials and Methods}

\section{Bacterial strains and preparation}

S. aureus producing enterotoxin A (ATCC 13565) and D (ATCC 23235) strains were obtained from Gyeong Sang University, and wild type, enterotoxin C was obtained from the Korea Food and Drug Administration (KFDA). B. cereus (ATCC 11778) was purchased from the Korean Federation of Culture Collections (KFCC). The $S$. aureus and B. cereus cultures were maintained in $10 \mathrm{~mL}$ of tryptic soy broth (TSB, Difco, USA) and nutri- ent broth (NB, Difco, USA) containing 20\% glycerol at $-80^{\circ} \mathrm{C}$, respectively. The stock cultures were thawed at room temperature and then $10 \mu \mathrm{L}$ was inoculated into a flask containing $10 \mathrm{~mL}$ of sterile TSB or NB under aseptic conditions. The flasks of TSB and NB were sealed with foam plugs and incubated on a rotary shaker (140 rpm) for $24 \mathrm{~h}$ at $35^{\circ} \mathrm{C}$ and $30^{\circ} \mathrm{C}$ under aerobic conditions, respectively. Both cultures were grown until the late exponential phase of growth $(>8 \log \mathrm{CFU} / \mathrm{mL})$. Under aseptic conditions, $1 \mathrm{~mL}$ of each culture was serially diluted into $9 \mathrm{~mL}$ of $0.1 \%$ sterile peptone water (Peptone, Difco, USA) or phosphate buffer solution (PBS), respectively.

\section{Preparation of samples with various food matrices}

By consideration of the primary compositions of commercial RTE foods, sliced bread, cooked rice, boiled Chinese noodles, boiled soybean sprouts, smoked chicken, tofu, baked fish, and hamburger patties were prepared as model foods in the present study. The sliced bread was purchased from a local bakery and used within an hour. Sterile, precooked rice was purchased from a local grocery store and reheated in a microwave for $150 \mathrm{sec}$ according to the cooking directions of the manufacture. The Chinese noodles and raw soybean sprouts were purchased from a local grocery store and were boiled in water for $6 \mathrm{~min}$ and $15 \mathrm{~min}$, respectively. The smoked chicken was purchased from a convenience store and was cooked for $120 \mathrm{sec}$ in a microwave. The tofu was purchased from a local grocery store and used within an hour. The fish (frozen pollack) and hamburger patties were purchased from a local grocery store and were baked without oil for $3 \mathrm{~min}$ and $4 \mathrm{~min}$, respectively. Since $S$. aureus and $B$. cereus were not detected in these samples, we cut them into $10 \mathrm{~g}$ portions and placed them into Petri dishes under aseptic conditions.

\section{Measurements of $\mathbf{p H}, \mathrm{Aw}$, and salt concentration}

The $\mathrm{pH}$ measurements were carried out with a $\mathrm{pH}$ meter (IQ Scientific Instruments, USA) using $10 \mathrm{~g}$ of sample mixed with $90 \mathrm{~mL}$ of $0.1 \%$ peptone water. Water activity was determined with an AquaLab Lite meter (Decagon, USA). The water activity meter was calibrated using a calibration solution of $6 \mathrm{M} \mathrm{NaCl}$. The salt concentration was measured by the Mohr method (AOAC, 1995). For the direct titration method, $10 \mathrm{~g}$ of weighed sample was placed into a $250 \mathrm{~mL}$ Erlenmeyer flask with $90 \mathrm{~mL}$ of distilled water and allowed to stand for 5 to 10 min with occasional swirling. Two milliliters of 5\% 
$\mathrm{K}_{2} \mathrm{CrO}_{4}$ solution was added as an indicator. The solution was titrated with $0.1 \mathrm{~N} \mathrm{AgNO}_{3}$ until an orange-brown color developed and persisted for $30 \mathrm{sec}$. Three replicates of each sample were tested and the measurements were repeated twice.

\section{Inoculation and enumeration}

A $100 \mu \mathrm{L}$ cocktail of the three strains of $S$. aureus or $B$. cereus was inoculated onto each surface of the various food matrices (sliced bread, cooked rice, boiled Chinese noodles, boiled soybean sprouts, tofu, smoked chicken, baked fish, and hamburger patties). The target population was approximately $3.0 \log \mathrm{CFU} / \mathrm{g}$. Each inoculated food was stored at temperatures of $8,10,13,17,24$, and $30^{\circ} \mathrm{C}$, respectively, to develop the primary growth models for $S$. aureus and B. cereus. These samples were then diluted as appropriate, and plated in duplicate onto Baird-parker agar or TSA for $S$. aureus, and PEMBA or NA for $B$. cereus, followed by aerobic incubation at $35^{\circ} \mathrm{C}$ or $30^{\circ} \mathrm{C}$ for $24 \mathrm{~h}$, respectively. The colonies from the duplicate plates were counted and the counts were converted to log scale.

\section{Predictive growth models for $S$. aureus and $B$. cereus}

The growth kinetic parameters including lag time (LT) and specific growth rate (SGR) in the primary model were determined at each temperature with the Gompertz equation (Gibson et al., 1987) using GraphPad Prism V4.0 (GraphPad Sofrware, USA).

$$
\mathrm{Y}=\mathrm{No}+\mathrm{C} * \exp (-\exp ((2.718 * \mathrm{SGR} / \mathrm{C}) *(\mathrm{Lag}-\mathrm{t})+1))
$$

Where $\mathrm{Y}$ is the viable cell count ( $\log \mathrm{CFU}$ per $\mathrm{g}$ ), $\mathrm{N}_{0}$ is the initial $\log$ number of cells, $\mathrm{C}$ is the difference between the initial and final cell numbers, SGR is specific growth rate $(\log / \mathrm{h}), \mathrm{Lag}$ is the lag time (LT) before growth and $\mathrm{t}$ is sampling time.

\section{Secondary modeling}

The LT and SGR values of primary model at each temperature were further used in the Davey (1989) model and Square-root model (Ratkowsky et al., 1982), respectively, as a function of temperature.

$$
\text { Davey model : } \mathrm{Y}=\mathrm{a}+(\mathrm{b} / \mathrm{T})+\left(\mathrm{c} / \mathrm{T}^{2}\right)
$$

Where $\mathrm{Y}$ is lag time, a, b, c are constant, and $\mathrm{T}$ is temperature.
Square-root model: $\mathrm{Y}=\{\mathrm{b}(\mathrm{T}-\mathrm{Tmin})\}^{2}$

Where $\mathrm{Y}$ is specific growth rate, $\mathrm{b}$ is constant, and $\mathrm{T}$ is temperature.

\section{Evaluation of model performance}

In order to evaluate the model performance of the secondary models, both bias $\left(\mathrm{B}_{f}\right)$ and accuracy $\left(\mathrm{A}_{f}\right)$ factors were calculated as follows (Ross, 1996; Abou-zeid et al., 2009):

$$
\begin{aligned}
& \mathrm{B}_{f} \text { for } \mathrm{LT}=10^{\sum \log (\text { predicted/observed)/n }} \\
& \mathrm{A}_{f} \text { for } \mathrm{LT}=10^{(\Sigma \mid \log (\text { predicted/observed }) / \mathrm{n})} \\
& \mathrm{B}_{f} \text { for } \mathrm{SGR}=10^{\Sigma \log (\text { observed/predicted }) / \mathrm{n}} \\
& \mathrm{A}_{f} \text { for } \mathrm{SGR}=10^{(\Sigma \mid \log (\text { observed/predicted }) / \mathrm{n})}
\end{aligned}
$$

Where the mean values of $\mathrm{B}_{f}$ and $\mathrm{A}_{f}$ were used as overall measures of model prediction bias and accuracy, respectively. Different ratios were used for the LT and SGR values so that $\mathrm{B}_{f}$ less than one represent fail-safe predictions and $\mathrm{B}_{f}$ greater than one represent fail-dangerous predictions. $\mathrm{B}_{f}$ consider whether predictions are more in the fail-safe direction or not. Acceptable values for $\mathrm{B}_{f}$ are the range of 0.700 to 1.150 . In contrast, acceptable $\mathrm{A}_{f}$ are dependent on the number of model variables and $\mathrm{A}_{f}$ does not consider that predictions error are more in the fail-safe directions (Oscar, 2005).

\section{Statistical analysis}

The experiment was repeated twice and the obtained results were analyzed using the SAS (Statistical Analysis System) program. The data are expressed as means \pm standard deviations (SD). The significant differences among the groups were determined by analysis of variance (ANOVA) and the means were separated using Duncan's multiple range tests $(p<0.05)$.

\section{Results and Discussion}

\section{Development of growth models for $S$. aureus on various food matrices}

In the present study, various food matrices having primary compositions based on carbohydrate, vegetable protein, and animal protein, were used as model foods to predict the growth of $S$. aureus as a function of temperature. The initial contamination levels of $S$. aureus on the various food matrices were between 2.9 and $3.4 \log$ CFU/ g. However, initial population density did not affect the growth kinetics of $S$. aureus, regardless of the various 
food matrices or storage temperatures (data not shown).

As shown in Table 1, the $\mathrm{pH}$ of the cooked rice was 6.61, which was the lowest $\mathrm{pH}$ among the model foods tested, followed by tofu (6.96), boiled soybean sprouts (7.09), boiled Chinese noodles (7.43), baked fish (7.50), hamburger patties (7.52), sliced bread (7.66), and smoked chicken (7.97). On the other hand, the lowest Aw was measured in the smoked chicken (0.94), followed by sliced bread and hamburger patties (0.95), tofu (0.98), baked fish and cooked rice (0.99), and boiled Chinese noodles and boiled soybean sprouts (1.00). The salt concentrations of the sliced bread, smoked chicken, hamburger patties, and baked fish were $0.17,0.44,0.47$, and $0.81 \%(\mathrm{w} / \mathrm{w})$, respectively, while the cooked rice, boiled Chinese noodles, boiled soybean sprouts, and tofu did not contain salt.

Predictive models as a food-safety tool are available in the USDA PMP (Pathogen Modeling Program), and are potentially useful in the development and maintenance of HACCP systems. However, as most of the PMP models are based on data from the microbial behavior of healthy cells in liquid microbiological media, these models should be validated for each specific food product before they are used (Johnson, 1984; Pepe et al., 2006). In addition, unstressed cells grown in rich media in the laboratory probably do not accurately represent the physiology of cells found in food environments (Leyer and Johnson, 1993). According to the PMP, the $\mathrm{pH}$ range of media is 4.5 to 9 and the range of sodium chloride is 0.5 to $12.5 \%$. In the present study, we also compared the growth kinetics of $S$. aureus on hamburger patties $(0.47 \%)$ and baked fish $(0.81 \%)$ under aerobic conditions to those with $0.5 \%$ and $0.8 \%$ sodium chloride in PMP. The LTs of $S$. aureus grown in $0.5 \%$ and $0.8 \%$ sodium chloride under aerobic conditions at $10^{\circ} \mathrm{C}$ and $\mathrm{pH} 7.5$ were determined as 1.64 and 1.76 days, respectively, for PMP, which are similar to the LT values of $S$. aureus at $10^{\circ} \mathrm{C}$ and $\mathrm{pH} 7.5$ that resulted from the present study (Table 2). However, differences between the growth characteristics of $S$. aureus from PMP and those in current study were lessened as the incubation temperature increased above $13^{\circ} \mathrm{C}$.

In the present study, a modified Gompertz equation was used to make primary growth models of $S$. aureus on various food matrices. The primary growth models on vari-

Table 1. pH, $\mathbf{a}_{\mathrm{w}}$ and salt concentration of various food matrices

\begin{tabular}{cccccccccc}
\hline \hline & $\begin{array}{c}\text { Boiled } \\
\text { Chinese noodle }\end{array}$ & $\begin{array}{c}\text { Cooked } \\
\text { Rice }\end{array}$ & $\begin{array}{c}\text { Sliced } \\
\text { bread }\end{array}$ & Tofu & $\begin{array}{c}\text { Boiled Bean } \\
\text { Sprout }\end{array}$ & $\begin{array}{c}\text { Hamburger } \\
\text { patties }\end{array}$ & $\begin{array}{c}\text { Smoked } \\
\text { Chicken }\end{array}$ & $\begin{array}{c}\text { Baked } \\
\text { Fish }\end{array}$ \\
\hline $\mathrm{pH}$ & 7.43 & 6.61 & 7.66 & 6.96 & 7.09 & 7.52 & 7.97 & 7.50 \\
$\mathrm{a}_{\mathrm{w}}$ & 1.00 & 0.99 & 0.95 & 0.98 & 1.00 & 0.95 & 0.94 & 0.99 \\
$\mathrm{Salt}(\mathrm{w} / \mathrm{v})$ & 0.00 & 0.00 & 0.17 & 0.00 & 0.00 & 0.47 & 0.44 & 0.81 \\
\hline
\end{tabular}

Values are means $(n=3)$.

Table 2. Observed specific growth rate (SGR) and lag time (LT) value of $S$. aureus

\begin{tabular}{|c|c|c|c|c|c|c|c|c|c|}
\hline \multicolumn{2}{|c|}{ Temp } & $\begin{array}{c}\text { Boiled } \\
\text { Chinese noodle }\end{array}$ & $\begin{array}{l}\text { Cooked } \\
\text { Rice }\end{array}$ & $\begin{array}{l}\text { Sliced } \\
\text { bread }\end{array}$ & Tofu & $\begin{array}{l}\text { Boiled Bean } \\
\text { Sprout }\end{array}$ & $\begin{array}{l}\text { Hamburger } \\
\text { patties }\end{array}$ & $\begin{array}{l}\text { Smoked } \\
\text { Chicken }\end{array}$ & $\begin{array}{l}\text { Baked } \\
\text { Fish }\end{array}$ \\
\hline \multirow{2}{*}{8} & $\mathrm{LT}^{1)}$ & $3.31^{\mathrm{b}}$ & $3.12^{\mathrm{bc}}$ & $5.25^{\mathrm{a}}$ & $2.86^{\mathrm{cd}}$ & $3.63^{b c}$ & $2.56^{\mathrm{d}}$ & $1.39^{\mathrm{e}}$ & $2.44^{\mathrm{d}}$ \\
\hline & $\mathrm{SGR}^{2)}$ & $0.40^{\mathrm{c}}$ & $0.31^{\mathrm{d}}$ & $0.14^{\mathrm{e}}$ & $0.34^{\mathrm{d}}$ & $0.31^{\mathrm{e}}$ & $0.42^{\mathrm{b}}$ & $0.48^{\mathrm{a}}$ & $0.43^{\mathrm{b}}$ \\
\hline \multirow{2}{*}{10} & $\mathrm{LT}$ & $1.70^{\mathrm{b}}$ & $1.44^{\mathrm{bc}}$ & $3.28^{\mathrm{a}}$ & $1.45^{\mathrm{cd}}$ & $1.39^{\mathrm{bc}}$ & $1.57^{\mathrm{bc}}$ & $0.96^{\mathrm{d}}$ & $1.56^{\mathrm{b}}$ \\
\hline & SGR & $0.72^{\mathrm{b}}$ & $0.68^{\mathrm{b}}$ & $0.13^{\mathrm{c}}$ & $0.64^{\mathrm{b}}$ & $0.63^{b}$ & $0.70^{\mathrm{b}}$ & $0.74^{\mathrm{b}}$ & $1.05^{\mathrm{a}}$ \\
\hline \multirow{2}{*}{13} & LT & $1.37^{\mathrm{b}}$ & $1.03^{\mathrm{cd}}$ & $2.29^{\mathrm{a}}$ & $1.22^{\mathrm{bc}}$ & $0.64^{\mathrm{de}}$ & $0.89^{\text {bcd }}$ & $0.52^{\mathrm{e}}$ & $0.54^{\mathrm{e}}$ \\
\hline & SGR & $1.34^{\mathrm{bc}}$ & $1.82^{\mathrm{a}}$ & $0.46^{\mathrm{c}}$ & $1.69^{\mathrm{ab}}$ & $1.90^{\mathrm{a}}$ & $1.23^{\mathrm{c}}$ & $1.36^{\mathrm{bc}}$ & $1.27^{\mathrm{c}}$ \\
\hline \multirow{2}{*}{17} & LT & $0.56^{\mathrm{b}}$ & $0.56^{\mathrm{b}}$ & $0.96^{\mathrm{a}}$ & $0.35^{\mathrm{b}}$ & $0.60^{\mathrm{b}}$ & $0.42^{\mathrm{b}}$ & $0.35^{\mathrm{b}}$ & $0.41^{\mathrm{b}}$ \\
\hline & SGR & $2.81^{\mathrm{b}}$ & $2.60^{\mathrm{b}}$ & $1.14^{\mathrm{a}}$ & $2.38^{\mathrm{b}}$ & $2.39^{\mathrm{b}}$ & $2.84^{\mathrm{b}}$ & $2.90^{\mathrm{b}}$ & $3.59^{\mathrm{a}}$ \\
\hline \multirow{2}{*}{24} & LT & $0.21^{\mathrm{cd}}$ & $0.22^{b c}$ & $0.28^{\mathrm{a}}$ & $0.27^{\mathrm{ab}}$ & $0.19^{d}$ & $0.19^{d}$ & $0.19^{d}$ & $0.16^{\mathrm{e}}$ \\
\hline & SGR & $9.01^{\mathrm{b}}$ & $11.32^{\mathrm{ab}}$ & $4.38^{\mathrm{c}}$ & $12.12^{\mathrm{a}}$ & $9.37^{\mathrm{b}}$ & $8.03^{\mathrm{b}}$ & $9.97^{b}$ & $6.89^{b}$ \\
\hline \multirow{2}{*}{30} & LT & $0.10^{\mathrm{e}}$ & $0.11^{\text {bd }}$ & $0.19^{\mathrm{a}}$ & $0.14^{\text {cde }}$ & $0.16^{\mathrm{bc}}$ & $0.14^{\text {bc }}$ & $0.15^{\mathrm{b}}$ & $0.14^{\text {cd }}$ \\
\hline & SGR & $14.18^{b c}$ & $15.93^{b}$ & $10.87^{\mathrm{d}}$ & $15.41^{\mathrm{b}}$ & $14.31^{\mathrm{bc}}$ & $13.68^{b}$ & $17.58^{\mathrm{a}}$ & $12.29^{\mathrm{c}}$ \\
\hline
\end{tabular}

Values are means $(n=3)$.

${ }^{1)}$ LT: lag time (d).

${ }^{2)}$ SGR: specific growth rate (Log CFU/g/d).

${ }^{\mathrm{a}-\mathrm{e}}$ Means in a row with different superscript differ significantly $(p<0.05)$. 
ous food matrices fitted to the modified Gompertz equation well with a high degree of goodness-of-fit $\left(\mathrm{R}^{2}=\right.$ 0.931 to 0.990 ). Since temperature has been singled out as the main factor in regulating the growth of $S$. aureus (Buchanan and Phillips, 1990), we compared the parameters of the primary growth model, including LT and SGR, in each food matrix at various storage temperatures. In the present study, there were differences in the growth kinetics of $S$. aureus in which it grew more rapidly on animal protein foods including hamburger patties, smoked chicken, and baked fish than on carbohydrate based foods including cooked rice and boiled Chinese noodles and vegetable protein foods. This indicated that the $\mathrm{pH}$ of each food model did not influence the growth kinetics of

\section{A. Carbohydrate-based foods}

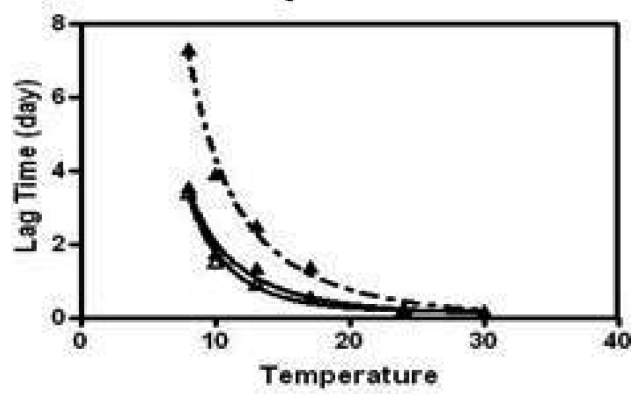

B. Vegetable protein foods

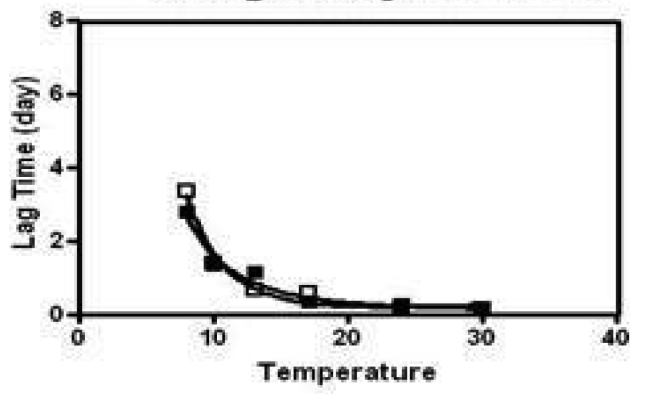

C. Animal protein foods

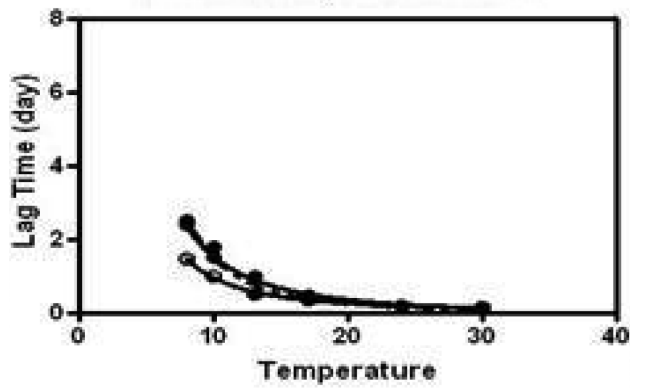

Fig. 1. Comparison of secondary model for Lag Time (LT) of $S$. aureus on various food matrices as a function of temperature. A. carbohydrate-based foods $\boldsymbol{\Delta}$, Boiled Chinese noodles $\triangle$, Cooked rice - $\boldsymbol{\Delta}$-, Sliced bread B. vegetable protein foods $\boldsymbol{\square}$, Tofu $\square$, Boiled soybean sprout C. animal protein foods $\boldsymbol{\bullet}$, Hamburger patties $\bigcirc$, Smoked chicken -0-, Baked fish.
S. aureus. Among the tested foods, S. aureus growth was most delayed on sliced bread (pH: 7.66, aw: 0.95, salt: $0.17 \%$ ) at all tested temperatures, while the fastest growth of $S$. aureus was observed in smoked chicken (pH: 7.97, aw: 0.94, salt: $0.44 \%$ ).

Secondary models were developed to describe the primary model parameters, including LT and SGR (Table 2), as a function of temperature. The Davey model for LT (Fig. 1) and square root model for SGR (Fig. 2) were used for each food as a function of temperature in which growth was possible. $\mathrm{B}_{f}$ and $\mathrm{A}_{f}$ values were also used to evaluate the ability of the predictive models to describe the experimental data adequately. The bias factor assesses whether a model is 'fail safe', whereas the accuracy fac-
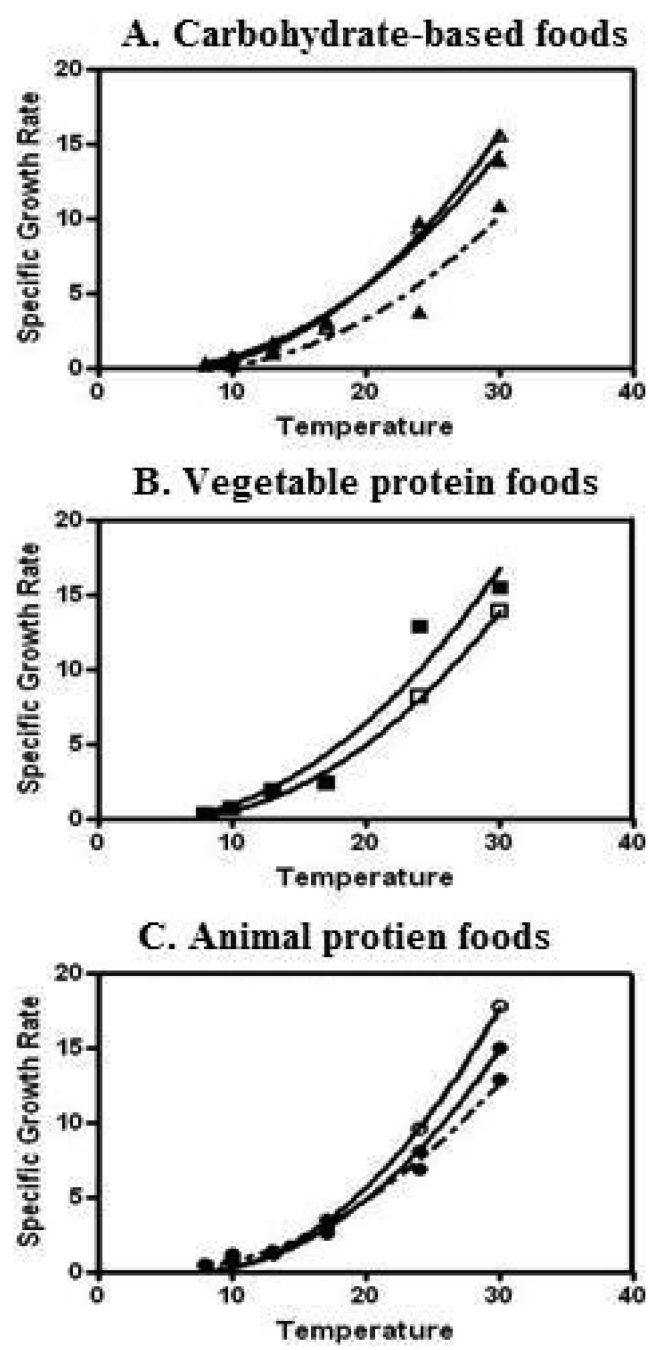

Fig. 2. Comparison of secondary model for Specific Growth Rate (SGR) of $S$. aureus on various food matrices as a function of temperature. A. carbohydrate-based foods $\boldsymbol{\Delta}$, Boiled Chinese noodles $\triangle$, Cooked rice - $\Delta$-, Sliced bread B. vegetable protein foods $\boldsymbol{\square}$, Tofu $\square$, Boiled soybean sprout C. animal protein foods $\bullet$, Hamburger patties $\bigcirc$, Smoked chicken - - - Baked fish. 
tor indicates by how much, on average, a prediction differs from the observed data. An acceptable range of $\mathrm{B}_{f}$ is 0.7 to 1.15 (Oscar, 2002). According to the model performance results (Table 3), both the $\mathrm{B}_{f}$ and $\mathrm{A}_{f}$ values of the LT and SGR models were close to 1, indicating that the induced secondary models had suitable performance to predict the growth of $S$. aureus in each food matrix used in the present study.

For the LT model, the range of $\mathrm{B}_{f}$ values on various food matrices was 0.94 to 1.05 , indicating that the predictions were in the acceptable range in the present study

Table 3. Model Performance of growth models for $S$. aureus and B.cereus

\begin{tabular}{|c|c|c|c|c|c|}
\hline \multirow{2}{*}{ Food } & & \multicolumn{2}{|c|}{ S. aureus } & \multicolumn{2}{|c|}{ B.cereus } \\
\hline & & $\mathrm{B}_{f}$ & $\mathrm{~A}_{f}$ & $\mathrm{~B}_{f}$ & $\mathrm{~A}_{f}$ \\
\hline \multirow{2}{*}{$\begin{array}{c}\text { Boiled } \\
\text { Chinese noodle }\end{array}$} & $\mathrm{LT}^{1)}$ & 1.04 & 1.12 & 0.97 & 1.25 \\
\hline & $\mathrm{SGR}^{2)}$ & 1.11 & 1.22 & 1.09 & 1.18 \\
\hline \multirow{2}{*}{ Cooked Rice } & LT & 1.05 & 1.2 & 1.00 & 1.13 \\
\hline & SGR & 0.98 & 1.15 & 0.96 & 1.09 \\
\hline \multirow{2}{*}{ Sliced bread } & LT & 0.94 & 1.26 & 1.02 & 1.09 \\
\hline & SGR & 0.93 & 1.37 & 0.92 & 1.24 \\
\hline \multirow{2}{*}{ Tofu } & LT & 1.03 & 1.19 & 1.02 & 1.12 \\
\hline & SGR & 0.92 & 1.15 & 0.94 & 1.13 \\
\hline \multirow{2}{*}{$\begin{array}{l}\text { Boiled Bean } \\
\text { Sprout }\end{array}$} & LT & 1.01 & 1.35 & 1.04 & 1.31 \\
\hline & SGR & 1.05 & 1.19 & 0.92 & 1.16 \\
\hline \multirow{2}{*}{$\begin{array}{l}\text { Hamburger } \\
\text { patties }\end{array}$} & LT & 0.99 & 1.06 & 1.00 & 1.05 \\
\hline & SGR & 1.20 & 1.27 & 0.99 & 1.09 \\
\hline \multirow{2}{*}{$\begin{array}{l}\text { Smoked } \\
\text { Chicken }\end{array}$} & LT & 1.00 & 1.04 & 0.99 & 1.16 \\
\hline & SGR & 1.16 & 1.24 & 0.9 & 1.19 \\
\hline \multirow{2}{*}{ Baked Fish } & LT & 1.00 & 1.11 & 1.00 & 1.14 \\
\hline & SGR & 1.04 & 1.15 & 0.91 & 1.17 \\
\hline
\end{tabular}

${ }^{1)}$ LT: lag time (d).

${ }^{2)}$ SGR: specific growth rate (Log CFU/g/d).
(Table 3). For the SGR model, the highest $\mathrm{B}_{f}$ of 1.20 was calculated in hamburger patties, followed by smoked chicken (1.16). Except these two foods, the range of $\mathrm{B}_{f}$ values in SGR model was in the acceptable range. Evaluation of the ability of a model to predict the data used to develop it (verification) is important because a model that does not properly fit the data used to develop it would not provide predictions within or beyond its response surface. Therefore, interpolation and extrapolation with independent sets of data are important for the proper evaluation of model performance (Oscar, 2005). Overall, the $\mathrm{B}_{f}$ values of the LT model were more close to 1 compared to the SGR model, indicating that the LT model was more accurate and had lower prediction bias than the SGR model. Comparisons of the best-fit values for SGR and LT were also made by $\mathrm{R}^{2}$ (the coefficient of determination). Overall, the LT model had a better performance than the SGR model in the present study.

\section{Development of growth models for $B$. cereus on various food matrices}

Since $B$. cereus growth was not observed at 8 and $10^{\circ} \mathrm{C}$, the primary growth models for $B$. cereus on the various foods were developed at $13,17,24$ and $30^{\circ} \mathrm{C}$. B. cereus cells need a rich medium for growth at low temperatures, but the results obtained in different foods and conditions may be not similar. In agreement to our results, Schultz and Smith (Schultz and Smith, 1994) indicated that meat is a better substrate than laboratory medium for the growth of some strains of B. cereus (Sidonia et al., 2007). The primary growth models of $B$. cereus on the various food matrices fitted to the modified Gompertz equation well, with a high degree of goodness-of-fit $\left(\mathrm{R}^{2}=0.922\right.$ to $0.998)$. In the primary growth models of $B$. cereus, SGR

Table 4. Observed specific growth rate (SGR) and lag time (LT) value of B. cereus

\begin{tabular}{ccccccccccc}
\hline \hline \multirow{2}{*}{ Temp } & $\begin{array}{c}\text { Boiled } \\
\text { Chinese noodle }\end{array}$ & $\begin{array}{c}\text { Cooked } \\
\text { Rice }\end{array}$ & $\begin{array}{c}\text { Sliced } \\
\text { bread }\end{array}$ & Tofu & $\begin{array}{c}\text { Boiled } \\
\text { Bean Sprout }\end{array}$ & $\begin{array}{c}\text { Hamburger } \\
\text { patties }\end{array}$ & $\begin{array}{c}\text { Smoked } \\
\text { Chicken }\end{array}$ & $\begin{array}{c}\text { Baked } \\
\text { Fish }\end{array}$ \\
\hline \multirow{2}{*}{13} & $\mathrm{LT}^{\mathrm{l})}$ & $2.58^{\mathrm{c}}$ & $2.44^{\mathrm{d}}$ & $3.01^{\mathrm{a}}$ & $1.63^{\mathrm{f}}$ & $1.85^{\mathrm{f}}$ & $2.05^{\mathrm{e}}$ & $2.82^{\mathrm{b}}$ & $2.57^{\mathrm{c}}$ \\
& $\mathrm{SGR}^{2)}$ & $1.01^{\mathrm{cd}}$ & $0.95^{\mathrm{d}}$ & $0.57^{\mathrm{e}}$ & $1.53^{\mathrm{a}}$ & $1.41^{\mathrm{a}}$ & $1.34^{\mathrm{b}}$ & $1.11^{\mathrm{c}}$ & $1.02^{\mathrm{c}}$ \\
\hline \multirow{2}{*}{17} & $\mathrm{LT}$ & $0.72^{\mathrm{d}}$ & $0.82^{\mathrm{c}}$ & $1.09^{\mathrm{a}}$ & $0.68^{\mathrm{e}}$ & $0.61^{\mathrm{e}}$ & $0.81^{\mathrm{c}}$ & $0.90^{\mathrm{b}}$ & $0.86^{\mathrm{b}}$ \\
& $\mathrm{SGR}$ & $1.57^{\mathrm{e}}$ & $2.00^{\mathrm{d}}$ & $2.00^{\mathrm{d}}$ & $3.44^{\mathrm{a}}$ & $3.45^{\mathrm{a}}$ & $2.47^{\mathrm{c}}$ & $2.92^{\mathrm{b}}$ & $2.71^{\mathrm{bc}}$ \\
\hline \multirow{2}{*}{24} & LT & $0.25^{\mathrm{f}}$ & $0.26^{\mathrm{f}}$ & $0.56^{\mathrm{a}}$ & $0.25^{\mathrm{f}}$ & $0.27^{\mathrm{ef}}$ & $0.28^{\mathrm{c}}$ & $0.28^{\mathrm{d}}$ & $0.29^{\mathrm{b}}$ \\
& $\mathrm{SGR}$ & $5.15^{\mathrm{d}}$ & $6.34^{\mathrm{c}}$ & $2.63^{\mathrm{e}}$ & $9.61^{\mathrm{a}}$ & $9.60^{\mathrm{a}}$ & $8.35^{\mathrm{b}}$ & $9.61^{\mathrm{a}}$ & $8.93^{\mathrm{ab}}$ \\
\hline \multirow{2}{*}{30} & LT & $0.16^{\mathrm{bc}}$ & $0.14^{\mathrm{d}}$ & $1.26^{\mathrm{a}}$ & $0.09^{\mathrm{e}}$ & $0.08^{\mathrm{e}}$ & $0.17^{\mathrm{b}}$ & $0.16^{\mathrm{b}}$ & $0.16^{\mathrm{b}}$ \\
& SGR & $9.81^{\mathrm{b}}$ & $9.85^{\mathrm{b}}$ & $3.82^{\mathrm{c}}$ & $13.63^{\mathrm{a}}$ & $13.31^{\mathrm{a}}$ & $13.74^{\mathrm{a}}$ & $13.78^{\mathrm{a}}$ & $13.15^{\mathrm{a}}$ \\
\hline
\end{tabular}

Values are means $(\mathrm{n}=3)$.

${ }^{1)}$ LT: lag time (d).

${ }^{2)}$ SGR: specific growth rate (Log CFU/g/d).

${ }^{\mathrm{a}-\mathrm{f}}$ Means in a row with different superscript differ significantly $(p<0.05)$. 
and LT were mainly affected by temperature and food matrix composition (Table 4).

According to the primary food matrix composition, significant differences in $B$. cereus growth kinetics were observed. At $13^{\circ} \mathrm{C}, B$. cereus growth was significantly ( $p$ $<0.05$ ) more rapid on vegetable protein foods including tofu and boiled bean sprouts than on carbohydrate-based foods such as cooked rice, boiled Chinese noodles, and sliced bread. Although no significant differences in the growth kinetics of $B$. cereus were observed between the protein and carbohydrate-based foods at 17,24 , and $30^{\circ} \mathrm{C}$, $B$. cereus showed more rapid growth on the hamburger patties, smoked chicken, tofu, boiled bean sprouts, and

\section{A. Carbohydrate-based foods}

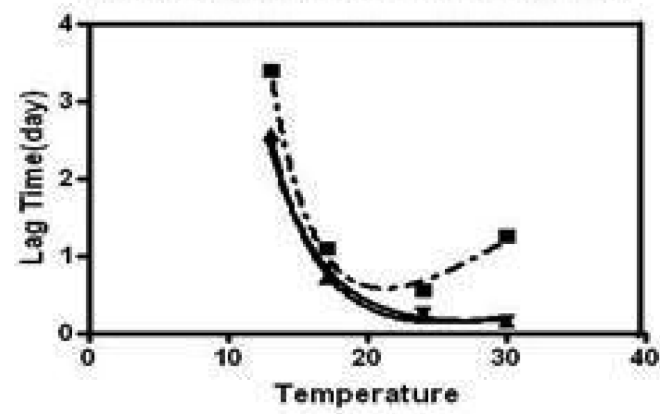

B. Vegetable protein foods

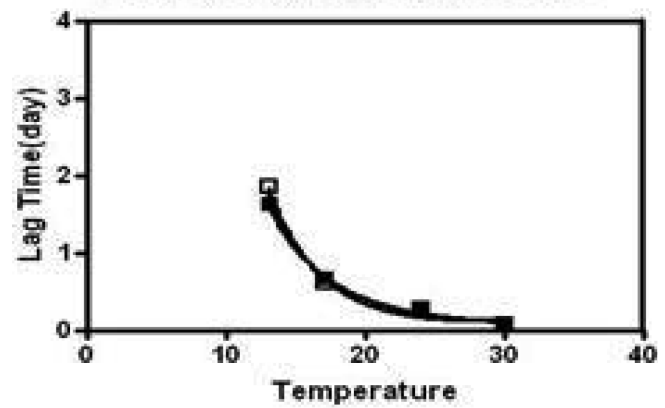

C. Animal protein foods

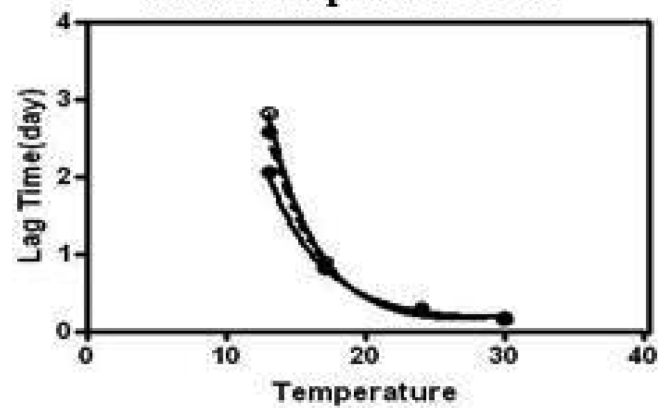

Fig. 3. Comparison of secondary model for Lag Time (LT) of $B$. cereus on various food matrices as a function of temperature. A. carbohydrate-based foods $\boldsymbol{\Delta}$, Boiled Chinese noodles $\triangle$, Cooked rice - $\mathbf{\Delta}$-, Sliced bread B. vegetable protein foods $\boldsymbol{\square}$, Tofu $\square$, Boiled soybean sprout C. animal protein foods $\boldsymbol{O}$, Hamburger patties $\bigcirc$, Smoked chicken - -, Baked fish. baked fish than on the boiled Chinese noodles, cooked rice, and sliced bread at all temperatures. Among the carbohydrate-based foods, the sliced bread showed the slowest growth as indicated by the growth kinetics of $S$. aureus.

In comparison to the B. cereus growth model in PMP under aerobic conditions at $\mathrm{pH} 7.5$ and $0.5 \%$ sodium chloride, the growth kinetics of $B$. cereus on the hamburger patties and baked fish were compared at 13, 24, and $30^{\circ} \mathrm{C}$. At $13^{\circ} \mathrm{C}$, the LTs of B. cereus in Pathogen Modeling Program (PMP) with $0.5 \%$ and $0.8 \%$ sodium chloride under aerobic conditions at $\mathrm{pH} 7.5$ were 2.414 days and 2.651 days, respectively, which were similar to
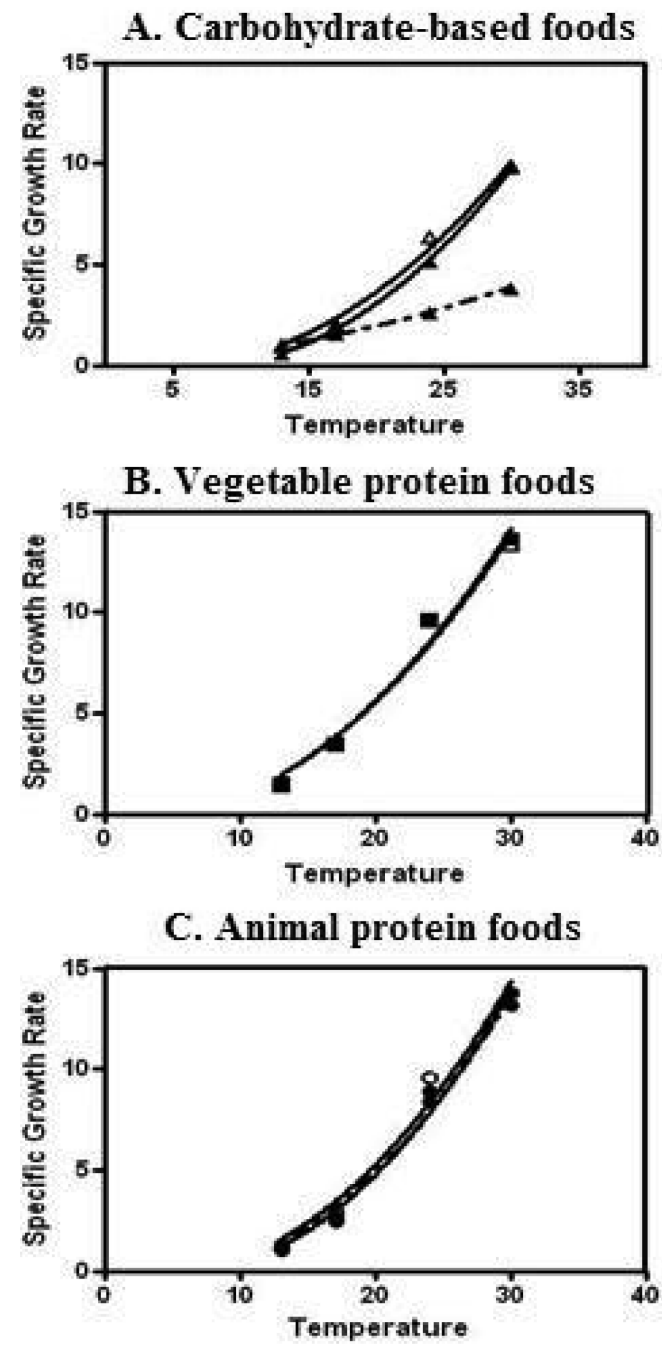

Fig. 4. Comparison of secondary model for Specific Growth Rate (SGR) of $B$. cereus on various food matrices as a function of temperature. A. carbohydrate-based foods $\boldsymbol{\Delta}$, Boiled Chinese noodles $\triangle$, Cooked rice - $\mathbf{\Delta}$-, Sliced bread B. vegetable protein foods $\square$, Tofu $\square$, Boiled soybean sprout C. animal protein foods $\bullet$, Hamburger patties $\bigcirc$, Smoked chicken - - - Baked fish. 
the obtained LT values of $B$. cereus measured in the present study under the same conditions. However, the growth kinetics of $B$. cereus were different from those observed in PMP at higher temperatures such as 24 and $30^{\circ} \mathrm{C}$.

Secondary models were also developed to describe the primary model parameters including LT (Fig. 3) and SGR (Fig. 4) as a function of temperature. The model described by Davey was used to evaluate the LT in each food as a function of temperature, namely at $13,17,24$, or $30^{\circ} \mathrm{C}$ where growth was possible. Since $B$. cereus growth was not observed at 8 and $10^{\circ} \mathrm{C}$, these temperatures were not included in the development of the secondary models. Comparisons of the best-fit values for SGR and LT, as indicated by $\mathrm{R}^{2}$ (the coefficient of determination), are presented in Table 3.

In the secondary models for B. cereus, the LT values of carbohydrate foods tended to be longer than those of vegetable protein foods. In particular, the LTs of sliced bread were the longest at all temperatures. Overall, the LT values of animal protein foods were longer than those of vegetable protein foods at lower temperatures (Fig. 4). The SGR values of carbohydrate foods tended to have similar trends at lower temperature, but differences were noticed as temperature increased. Overall, the SGR values of the carbohydrate foods were lower than those of the vegetable and animal protein foods.

In this study, the bias factor $\left(\mathrm{B}_{f}\right)$ and accuracy factor $\left(\mathrm{A}_{f}\right)$, as indexes of model performance, were used to evaluate the ability of the developed growth models to describe the experimental data adequately (Table 3 ). The results show that both the $\mathrm{B}_{f}$ and $\mathrm{A}_{f}$ values of the SGR and LT models were close to 1 , indicating that the induced secondary models had suitable performance to predict the growth of $B$. cereus in each food matrices. For the Davey LT models of $B$. cereus, the $\mathrm{B}_{f}$ values of the boiled Chinese noodles (0.97), cooked rice (1.00), sliced bread (1.02), tofu (1.02), boiled soybean sprouts (1.04), hamburger patties (1.00), smoked chicken (0.99), and baked fish (1.00) were close to 1. For the SGR model, the $\mathrm{B}_{f}$ values of $B$. cereus on the boiled Chinese noodles (1.09), cooked rice (0.96), sliced bread (0.92), tofu (0.94), boiled soybean sprouts $(0.92)$, hamburger patties $(0.99)$, smoked chicken (0.90), and baked fish (0.91) indicated the predictions were generally fail-safe except for the boiled Chinese noodles, which was still in the acceptable range of 0.70 to 1.15 . On the other hand, the $A_{f}$ values of the SGR model were closer to 1 than those for the LT model (Table 3), indicating that overall the SGR model was more accurate and had a lower prediction bias than the LT model developed for the model foods tested in the present study.

In conclusion, the present study showed the growths of $S$. aureus and B. cereus to be the slowest on sliced bread. Furthermore, the critical food component for $S$. aureus growth was animal-based protein and for $B$. cereus growth, it was vegetable-based protein. Therefore, control of these microorganisms has great potential to extend the shelf life and safety of RTE foods consisting of these food matrices

\section{Acknowledgment}

This research was supported by the Kyung Hee University research fund in 2009(KHU-20091625).

\section{References}

1. Abou-Zeid, K. A., Oscar, T. P., Schwarz, J. G., Hashem, F. M., Whiting, R. C., and Yoon, K. S. (2009) Development and validation of a predictive model for Listeria monocytogenes scott a as a function of temperature, $\mathrm{pH}$ and commercial mixture of potassium lactate and sodium diacetate. J. Microbiol. Biotechnol. 19, 718-726.

2. Atanassova, V., Meindl, A., and Ring, C. (2001) Prevalence of Staphylococcus aureus and staphylococcal enterotoxins in raw pork and uncooked smoked ham - a comparison of classical culturing detection and RFLP-PCR. Int. J. Food Microbiol. 68, 105-113.

3. Buchanan, R. L. and Phillips, J. G. (1990) Response surface model for predicting the effects of temperature, $\mathrm{pH}$, sodium chloride content, sodium nitrite concentration and atmosphere on the growth of Listeria monocytogenes. Int. J. Food Prot. 53, 370-376.

4. Carlin, F., Fricker, M., Pielaat, A., heisterkamp, S., Shageen, R., Salonen, M. S., Svensson, B., Nguyen-the, C., and Mpnika, E. S. (2006) Emetic toxin-producing strains of Bacillus cereus show distinct characteristics within the Bacillus cereus group. Int. J. Food Microbiol. 109, 132-138.

5. Davey, K. R. (1989) A predictive model for combined temperature and water activity on microbial growth during the growth phase. J. Appl. Bacteriol. 67, 483-488.

6. Fujikawa, H. and Morozumi, S. (2006) Modeling Staphylococcus aureus growth and enterotoxin production in milk. Food Microbiol. 23, 260-267.

7. Gibson, A. M., Bratchell, N., and Roberts, T. A. (1987) The effect of sodium chloride and temperature on the rate and extent of growth Clostridium botulinum type A in pasteurized pork slurry. J. App. Bacteriol. 62, 479-490.

8. Gibson, A. M., Bratchell, N., and Roberts, T. A. (1988) Predicting microbial growth: growth responses of Salmonella in a laboratory medium as affected by $\mathrm{pH}$, sodium chloride, and 
storage temperature. Int. J. Food Microbiol. 6, 155-178.

9. Granum, P. E. (1994) Bacillus cereus and its toxins. J. Appl. Bacteriol. 76 Sppl, S61-S66.

10. Hiraki, J., Hatakeyama, M., Morita, H., Izumi, Y. (1998) Improved $\varepsilon$-poly-1-lysine production of an S-(20aminoethyl)-1cysteine resistant mutant of Streptomyces albulus. SeibutsuKogaku. 76, 487-493.

11. Johnson, K. M. (1984) Bacillus cereus food borne illness-an update. J. Food Prot. 47, 145-153.

12. Kim, J. Y., Kwon, I. K., Ha, S. Y., and Hong, C. H. (2005) Changes of contamination level of Listeria spp. During the proceeding environments in kimbab restaurants. J. Food Hygiene and Safety. 20, 232-236.

13. Leyer, G. J. and Johnson, E. A. (1993) Acid adaptation induces cross protection against environmental stresses in Salmonella Typhimurium. Appl. Environ. Microbiol. 59, 18421847.

14. Oscar, T. P. (2002) Development and validation of a tertiary simulation model for predicting the potential growth of Salmonella Typhimurium on cooked chicken. Int. J. Food Microbiol. 76, 177-190.

15. Oscar, T. P. (2005). Validation of lag time and growth rate models for Salmonella Typhimurium: acceptable prediction zone method. J. Food Sci. 70, M129-M137.

16. Park, S. Y., Choi, J. W., Yeon, J. H., Lee, M. J., Oh, D. H., and Hong, C. H. (2005) Assessment of contamination level of foodborne pathogens isolated in kimbab and its main ingredients in the process of preparation. Korean J. Food Sci. Technol. 37, 122-128.

17. Pepe, O., Blaiotta, G., Bucci, F., Anastasio, M., Aponte, M., and Villani, F. (2006) Staphylococcus aureus and staphylococcal enterotoxin A in breaded chicken products: detection and behavior during the cooking process. Appl. Environ. Microbiol. 72, 7057-7062.

18. Ratkowsky, D. A., Olley, J., McMeekin, T. A., and Ball, A. (1982) Relation between temperature and growth rate of bacteria cultures. J. Bacteriol. 149, 1-5.

19. Ross, T. (1996) Indices for performance evaluation of predictive models in food microbiology. J. Appl. Bacteriol. 81,
501-508.

20. Sidonia, M., Rubén, B., Inmaculada, F., and Javier, C. (2007) Effect of environmental parameters on growth kinetics of Bacillus cereus(ATCC 7004) after mild heat treatment. Int. J. Food Microbiol. 117, 223-227.

21. Simon, S. S. and Sanjeev, S. (2007) Prevalence of enterotoxigenic Staphylococcus aureus in fishery products and fish processing factory workers. Food Control. 18, 1565-1568.

22. Sneed, J., Strohbehn, C., Shirley, A. G., and Mendonca, J. (2004) Microbiological evaluation of foodservice contact surfaces in Iowa assisted-living facilities. J. Am. Diet. Assoc. 104, $1722-1724$.

23. Soriano, J. M., Font, G., Moltó, J. C., and Mañes, J. (2002) Enterotoxigenic staphylococci and their toxins in restaurant foods. Trends Food Sci. Technol. 13, 60-67.

24. AOAC (1995) Association of Official Analytical Chemists methods.

25. Hiraki, J., Suzuki, E., inventors; Chisso Corporation, assignee. (1999) Process for producing \&-polylysine with immobilized Streptomyces albulus. US patent, 5,900,363.

26. Korea Food and Drug Administration (2008) The report of foodborne illness in Korea. Available from : http://e-stat. kfda.go.kr/

27. Kramer, J. M. and Gilbert, R. J. (1989) Bacillus cereus and other Bacillus species. In: M.P. Doyle (ed) Foodborne Bacterial Pathogens, Marcel Dekker, Inc., New York, USA, pp. 2170.

28. Roberts, D. (1986) Factors contributing to outbreaks of foodborne infection and intoxicationin England and Wales 19701982. Proceedings of the $2^{\text {nd }}$ World Congress Foodborne Infections and Intoxications. Institute of Veterinary Medicine, Berlin, pp. 157-159.

29. Schultz, F. J. and Smith, J. L. (1994) Bacillus: recent advances in Bacillus cereus Food Poisoning Research. In: Hui, Y. H., Gorham, J. R., Murrell, K. D., Cliver, D. O. (Eds.), Foodborne Disease Handbook Diseases Caused by Bacteria. Marcel Dekker, Inc., New York, USA, pp. 29-62.

(Received 2010.5.30/Revised 1st 2010.8.14, 2nd 2010.9.9/ Accepted 2010.9.14) 